\title{
Statistical Analysis of Electric Power Distribution Grid Outages
}

\author{
Godwin Diamenu
}

\begin{abstract}
Power systems in general supply consumers with electrical energy as economically and reliably as possible. Reliable electric power systems serve customer loads without interruptions in supply voltage. Electric power generation facilities must produce enough power to meet customer demand. Electrical energy produced and delivered to customers through generation, transmission and distribution systems, constitutes one of the largest consumers markets the world over. The benefits of electric power systems are integrated into the much faster modern life in such extent that it is impossible to imagine the society without the electrical energy. The rapid growth of electric power distribution grids over the past few decades has resulted in a large increment in the number of grid lines in operation and their total length. These grid lines are exposed to faults as a result of lightning, short circuits, faulty equipment, mis-operation, human errors, overload, and aging among others. A fault implies any abnormal condition which causes a reduction in the basic insulation strength between phase conductors or phase conductors and earth, or any earthed screens surrounding the conductors. In this paper, different types of faults that affected the electric power distribution grid of selected operational districts of Electricity Company of Ghana (ECG) in the Western region of Ghana was analyzed and the results presented. Outages due to bad weather and load shedding contributed significantly to the unplanned outages that occurred in the medium voltage (MV) distribution grid. Blown fuse and loose contact faults were the major contributor to unplanned outages in the low voltage (LV) electric power distribution grid.
\end{abstract}

Index Terms - Electric Power Distribution Grid, Faults, Low Voltage (LV), Medium Voltage (MV), Outages.

\section{INTRODUCTION}

A power system basically comprises of a generating, a transmission and distribution systems. Power systems usually supply electrical energy to its customers in an economic and reliable manner as possible. An electric power system is one of the largest and the most complex systems established by mankind for comfort and survival. Electrical energy produced and delivered to customers through generation, transmission and distribution systems, constitutes one of the largest consumer markets in the world, and the demand for it is still growing. The benefits of electric power systems are integrated into the much faster modern life in such extent that it is impossible to imagine the society without the electrical energy. The world is so dependent on electricity in the 21 st century that any interruption or failure in the electric service system could lead to major disruption of daily life activities as well economic losses. Reliable electric power systems serve customer loads without interruptions in supply voltage throughout the year. Generation plants and facilities must produce enough power to meet customer demand. Electric power transmission systems must transport bulk power over long distances without overheating or jeopardizing system stability. Electric power distribution grids must deliver electrical energy to each customer's service entrance without interruption. Electric power transmission lines are used to transmit electric power to distant large load centers. The rapid growth of electric power grids over the past few decades have resulted in a large increase of the number of distribution lines in operation and their total length. These lines are exposed to faults as a result of lightning, short circuits, faulty equipment, mis-operation, human errors, overload, and aging among others. Many electrical faults manifest in mechanical damages, which must be repaired before returning the line into service. A fault on an electric power transmission lines implies any abnormal condition which causes a reduction in the basic insulation strength between phase conductors or phase conductors and earth, or any earthed screens surrounding the conductors. Such reduction of the insulation resistance is not considered as a fault until it produces some effect on an electric power grid. Again, until it results either in an excess current or in the reduction of the impedance between conductors and earth to a value below that of the lowest load impedance of the circuit. There are many causes of power failure in an electric power distribution grids. Examples include faults at substations stations, damage to electric transmission or distribution lines, short circuits, open circuits or the over loading of the electric power distribution lines. Electric power is conveyed from central and remote generation stations to a distant locations or centers for the end users by transmission and distribution grids with the distribution grids being the closest to the consumers. These electric power distribution grids can be radial or ring, but in most cases traditional radial network is adopted due to its low cost, simple protection schemes, facilitates network stability and reduction in number of protective devices. Radial network is a form of unidirectional power flow from the source to the load points or centers. The probability of failure or occurrence of abnormal condition is more in an overhead electric power transmission and distribution lines. This is due to their greater length, and exposure to the atmosphere without any form of protection [1]-[9].

Submitted on March 20, 2021

Published on April 12, 2021.

Godwin Diamenu, University of Health and Allied Sciences (UHAS), Ho,

Ghana.

(e-mail: alcatelgodwin@yahoo.co.uk) 


\section{FAULT INCIDENT RATES FOR DIFFERENT COMPONENTS OF AN ELECTRIC POWER SYSTEM}

Table I shows the contribution of fault incidents by each component of a power system to its failure [7].

TABLE I: FAULT INCIDENT RATES OF DIFFERENT COMPONENTS OF POWER SYSTEM WHICH CONTRIBUTES TO ITS FAILURE

\begin{tabular}{ccc} 
& \multicolumn{2}{c}{ POWER SYSTEM WHICH CONTRIBUTES TO ITS FAILURE } \\
\hline S/N & Component Name & Fault Incident Rate (\%) \\
\hline 1 & Cables & 10 \\
2 & Switch gears & 15 \\
3 & Transformers & 12 \\
4 & Current and Voltage Transformers & 2 \\
& (CTs and VTs) & 3 \\
7 & Control Equipment & 8 \\
\hline
\end{tabular}

\section{TYPES OF FAULTS IN ELECTRIC POWER DISTRIBUTION GRIDS}

Faults in an electric power distribution grids can be categorized as shunt faults (short circuits), series faults (open conductor), and simultaneous faults. Simultaneous faults are faults that occur more than one at the same time.

The types of shunt, series and simultaneous faults that do occur frequently in electric power distribution grids include:

1) Single phase to ground faults;

2) Single phase to ground faults through a resistor;

3) Double phase to ground faults;

4) Double phase faults;

5) Three phase faults;

6) Three phase to ground faults; and

7) Open circuit faults.

The appropriate percentages of occurrences of various line faults are as given in Table II [10].

\begin{tabular}{ccc}
\multicolumn{3}{c}{ TABLE II: TYPES OF FAULTS AND THEIR OCCURRENCE RATES } \\
S/N & Type of Fault & Occurrence Rate $(\%)$ \\
\hline 1 & Single line to ground fault & $70-80$ \\
2 & Line-Line to ground fault & $10-17$ \\
3 & Line-Line fault & $8-10$ \\
4 & Three phase & $2-3$
\end{tabular}

The various types of faults are indicated respectively in Fig.1-7 [11][15].

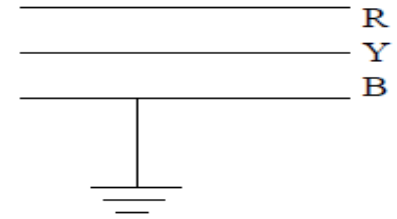

Fig. 1. Single Phase to Ground Fault.

$\mathrm{R}$

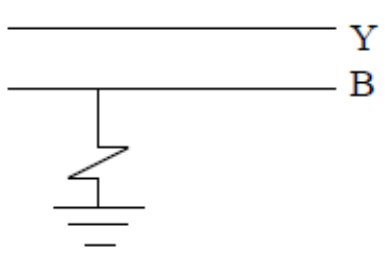

Fig. 2. Single Phase to Ground Fault through Resistor

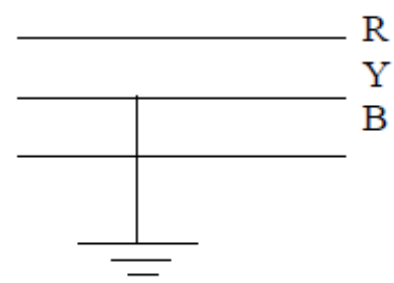

Fig. 3. Double Phase to Ground Fault.
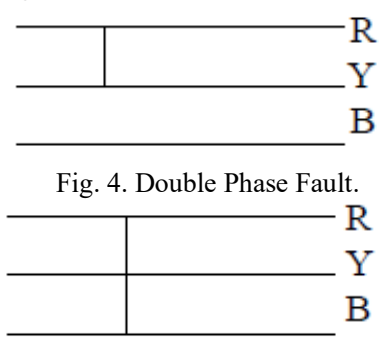

Fig. 5. Three Phase Fault

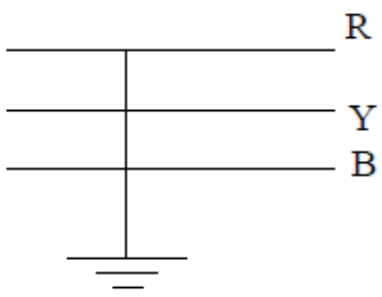

Fig. 6. Three Phase to Ground Fault.

Fig. 7. Open Circuit Fault

\section{NATURE AND CLASSIFICATION OF ELECTRIC POWER DISTRIBUTION GRID OUTAGES}

It has been reported in the literature that about $80 \%$ of the power outages are caused by the faults in the electric power distribution system. A fault is inevitable in an electric power distribution grid for many uncontrollable factors such as animals, and weather related factors. The nature of a fault is simply defined as any abnormal condition, which causes a reduction in the basic insulation resistance level between phase conductors, or between phase conductors and earth or any earthed screens surrounding the conductors. The main causes of an electric power grid line outages are lightning strokes, environmental or air pollution, and bush fires. Other causes of faults on overhead lines are falling trees, birds, flying aircraft, fog, ice, snow loading, punctured or broken insulators, open-circuit conductors and unnecessary over loading [14], [16], [17]. The occurrence of a fault results in system outage which usually affects the end users. A partial system outage describes a component state where the capacity of the component to perform its function is reduced but not completely eliminated. A total outage is system outage is where the component is completely incapable of performing its function as required.

A forced system outage is an outage that results from emergency conditions directly associated with a faulty component which must be taken out of service immediately either automatically or through switching operations. Forced outages can be associated with ageing equipment or defects, lightening strikes, wind, birds or animals, vandalisation, accidents and poor workmanship by electrical contractors. However, forced outages can be minimized if the system is 
properly designed and maintained but cannot be completely eliminated. Planned outages are outages due to planned or scheduled maintenance when a component is deliberately taken out of service at a selected time, usually for the purposes of construction, preventive maintenance or repairs. This could be either on the electric distribution grid or substation equipment. Emergency outages arise from loss of power supply from the generating station either due to inadequate generation or drop in the load coordination frequencies [8].

\section{MATERIALS AND Method}

The historical outage data used for the analyses was obtained from the regional office of the Electricity Company of Ghana (ECG). The regional office is in-charge of operation and maintenance of all electric power distribution networks within Western region of Ghana. The outage data is for a selected operational districts in the region for the years 2015 and 2016. The MS Excel was used in carrying out the analyses.
The analyses covered the $33 \mathrm{kV}$ and $11 \mathrm{kV}$ medium voltages (MV) as well as the low voltage (LV) electric power distribution grids of major towns and cities within the region. The tabulated monthly outages for the year 2015 are as given in Table III, Table IV and Table V respectively for the MV and LV networks. Summary of various faults and other factors that contributed to outages in the $33 \mathrm{kV}, 11 \mathrm{kV}$ and LV electric power distribution grids are also given in Table 6, Table VII and Table VIII respectively. Given in Table IX, Table X and Table XI respectively, are the tabulated monthly outages for the year 2016. Summary of various faults and other factors that contributed to outages in the MV and LV grids are also given in Table XII, Table XIII and Table XIV, respectively. Graphs of annual outages for the $33 \mathrm{kV}, 11 \mathrm{kV}$ and LV electric power distribution grids for the years 2015 and 2016 are as indicated in Fig. 8, Fig. 9 and Fig. 10, respectively. The $11 \mathrm{kV}$ electric power distribution grid operates in five operational districts. Graphs of outage durations for MV and LV electric power distribution grids are respectively given in Fig. 11-13.

\begin{tabular}{|c|c|c|c|c|c|c|c|c|c|c|c|c|c|}
\hline Operational Districts & Jan & Feb & March & April & May & June & July & Aug & Sept & Oct & Nov & Dec & Total \\
\hline Asankragwa & 29 & 54 & 53 & 93 & 72 & 40 & 27 & 34 & 40 & 69 & 46 & 21 & 578 \\
\hline Axim & 50 & 82 & 85 & 60 & 62 & 52 & 66 & 56 & 42 & 48 & 58 & 38 & 699 \\
\hline Bogoso & 44 & 90 & 87 & 72 & 50 & 46 & 56 & 52 & 37 & 74 & 80 & 58 & 746 \\
\hline Enchi & 32 & 29 & 36 & 45 & 16 & 44 & 38 & 41 & 47 & 34 & 52 & 14 & 428 \\
\hline Half Assini & 32 & 27 & 34 & 18 & 24 & 20 & 31 & 15 & 17 & 25 & 22 & 9 & 274 \\
\hline Sefwi Wiawso & 128 & 136 & 250 & 123 & 180 & 129 & 206 & 148 & 127 & 201 & 186 & 84 & 1898 \\
\hline Sekondi & 156 & 134 & 128 & 67 & 126 & 111 & 156 & 143 & 36 & 68 & 84 & 44 & 1253 \\
\hline Takoradi & 72 & 68 & 82 & 63 & 58 & 77 & 52 & 55 & 40 & 56 & 62 & 60 & 745 \\
\hline Tarkwa & 61 & 72 & 88 & 79 & 65 & 75 & 160 & 69 & 42 & 74 & 64 & 63 & 912 \\
\hline
\end{tabular}

\begin{tabular}{ccccccccccccccc} 
& \multicolumn{10}{c}{ TABLE IV: SuMMARY OF MONTHLY OUTAGES FOR THE 11 KV GRID FOR THE YEAR 2015 } \\
\hline Operational Districts & Jan & Feb & March & April & May & June & July & Aug & Sept & Oct & Nov & Dec & Total \\
\hline Axim & 6 & 10 & 8 & 9 & 7 & 11 & 14 & 12 & 10 & 9 & 8 & 13 & 117 \\
Sefwi Wiawso & 13 & 14 & 26 & 11 & 22 & 28 & 26 & 31 & 10 & 20 & 17 & 9 & 227 & 17 \\
Sekondi & 122 & 109 & 135 & 144 & 149 & 125 & 152 & 129 & 110 & 96 & 142 & 102 & 1515 \\
Takoradi & 305 & 268 & 354 & 440 & 480 & 436 & 344 & 214 & 141 & 135 & 267 & 213 & 3597 \\
Tarkwa & 72 & 84 & 92 & 75 & 85 & 72 & 114 & 54 & 45 & 59 & 68 & 61 & 881 \\
\hline
\end{tabular}

TABLE V: SUMMARY OF MONTHLY OUTAGES FOR THE LV GRID FOR THE YEAR 2015

\begin{tabular}{ccccccccccccccccc}
\hline Operational Districts & Jan & Feb & March & April & May & June & July & Aug & Sept & Oct & Nov & Dec & Total \\
\hline Asankragwa & 38 & 47 & 45 & 34 & 54 & 52 & 50 & 48 & 61 & 49 & 53 & 42 & 573 \\
Axim & 41 & 36 & 58 & 54 & 37 & 52 & 55 & 51 & 64 & 66 & 65 & 55 & 634 \\
Bogoso & 22 & 18 & 29 & 27 & 26 & 31 & 27 & 35 & 29 & 27 & 33 & 28 & 332 \\
Enchi & 35 & 28 & 25 & 32 & 17 & 24 & 32 & 40 & 52 & 47 & 39 & 24 & 395 \\
Half Assini & 45 & 42 & 88 & 55 & 59 & 54 & 64 & 46 & 57 & 53 & 62 & 41 & 666 \\
Sefwi Wiawso & 36 & 32 & 27 & 43 & 20 & 54 & 42 & 33 & 41 & 28 & 21 & 33 & 410 \\
Sekondi & 223 & 142 & 158 & 168 & 180 & 170 & 189 & 183 & 164 & 160 & 255 & 236 & 2228 \\
Takoradi & 265 & 213 & 271 & 226 & 278 & 257 & 222 & 272 & 257 & 272 & 328 & 275 & 3136 \\
Tarkwa & 126 & 134 & 98 & 82 & 70 & 48 & 41 & 55 & 109 & 125 & 74 & 83 & 1045 \\
\hline
\end{tabular}

TABLE VI: SUMMARY OF FAULTS IN THE 33 KV DISTRIBUTION GRID FOR THE YEAR 2015

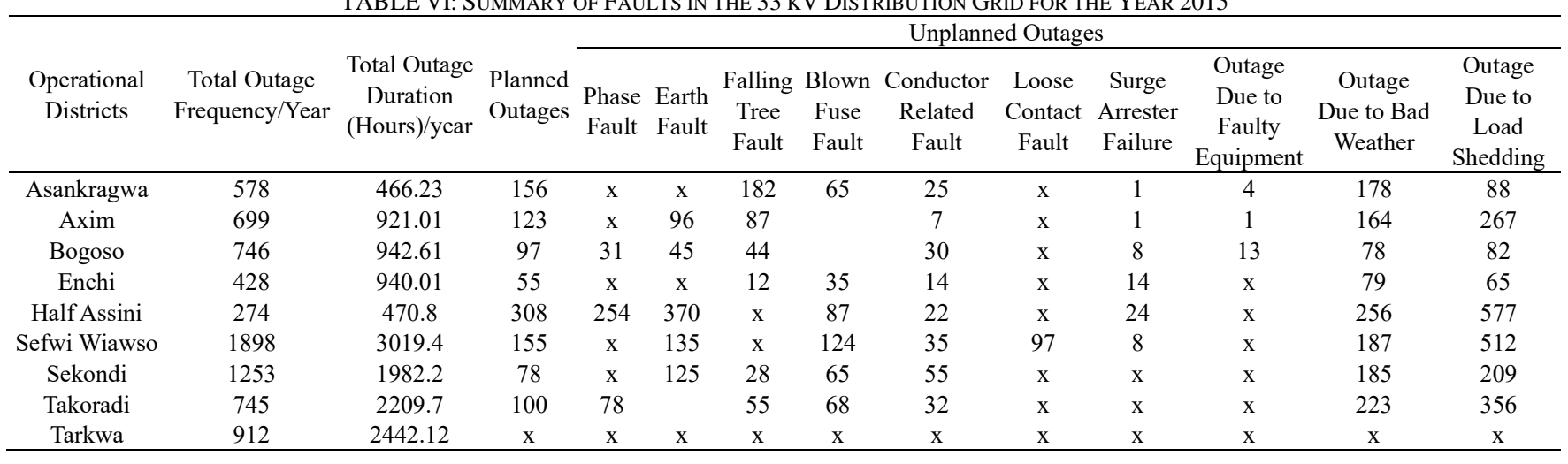


TABLE VII: SUMMARY OF FAULTS IN THE 11 KV DISTRIBUTION GRID FOR THE YEAR 2015

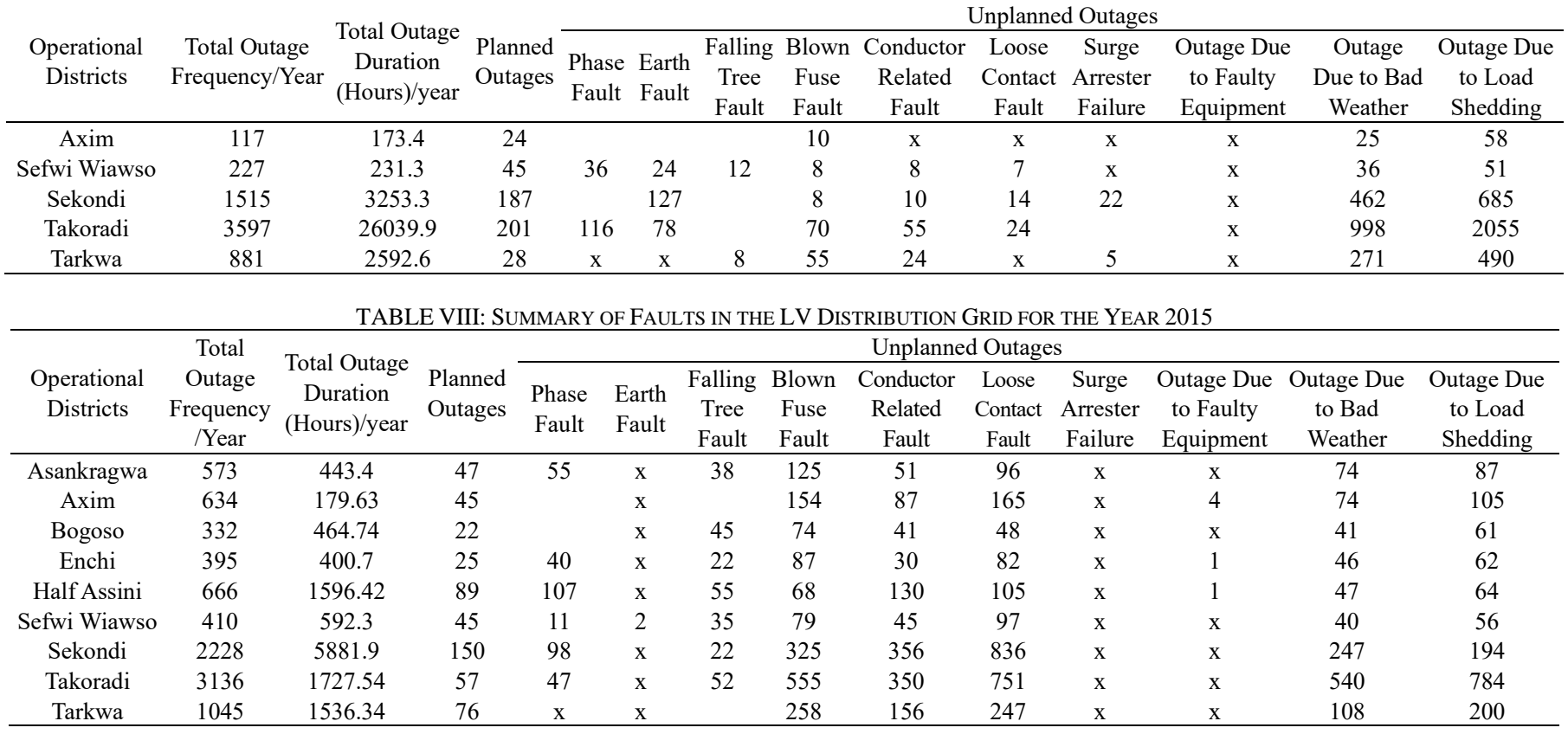

TABLE IX: SUMMARY OF MONTHLy OUTAGES FOR THE 33 KV GRID FOR THE YEAR 2016

\begin{tabular}{|c|c|c|c|c|c|c|c|c|c|c|c|c|c|}
\hline Operational Districts & Jan & Feb & March & April & May & June & July & Aug & Sept & Oct & Nov & Dec & Total \\
\hline Asankragwa & 42 & 45 & 59 & 57 & 69 & 52 & 59 & 51 & 53 & 63 & 48 & 59 & 657 \\
\hline Axim & 45 & 47 & 75 & 51 & 48 & 51 & 37 & 47 & 37 & 50 & 56 & 37 & 581 \\
\hline Bogoso & 75 & 129 & 119 & 92 & 123 & 102 & 48 & 56 & 42 & 55 & 73 & 61 & 975 \\
\hline Enchi & 11 & 17 & 23 & 28 & 25 & 21 & 29 & 43 & 28 & 32 & 14 & 27 & 298 \\
\hline Half Assini & 17 & 22 & 25 & 21 & 11 & 36 & 17 & 12 & 11 & 20 & 17 & 21 & 230 \\
\hline Sefwi Wiawso & 121 & 136 & 115 & 169 & 137 & 124 & 131 & 92 & 105 & 85 & 97 & 113 & 1425 \\
\hline Sekondi & 45 & 40 & 62 & 49 & 67 & 104 & 58 & 46 & 55 & 48 & 51 & 74 & 699 \\
\hline Takoradi & 29 & 49 & 70 & 51 & 62 & 55 & 63 & 58 & 77 & 58 & 57 & 39 & 668 \\
\hline Tarkwa & 27 & 26 & 31 & 30 & 38 & 42 & 43 & 31 & 12 & 23 & 25 & 32 & 360 \\
\hline
\end{tabular}

TABLE X: SUMMARY OF MONTHLY OUTAGES FOR THE $11 \mathrm{KV}$ GRID FOR THE YEAR 2016

\begin{tabular}{|c|c|c|c|c|c|c|c|c|c|c|c|c|c|}
\hline $\begin{array}{c}\text { Operational } \\
\text { Districts }\end{array}$ & Jan & Feb & March & April & May & June & July & Aug & Sept & Oct & Nov & Dec & Total \\
\hline Axim & 8 & 6 & 9 & 7 & 6 & 7 & 6 & 5 & 8 & 4 & 6 & 5 & 77 \\
\hline Sefwi Wiawso & 47 & 34 & 52 & 44 & 26 & 38 & 29 & 31 & 49 & 37 & 41 & 46 & 474 \\
\hline Sekondi & 64 & 55 & 74 & 85 & 71 & 236 & 92 & 87 & 82 & 30 & 43 & 59 & 978 \\
\hline Takoradi & 56 & 43 & 92 & 64 & 183 & 175 & 244 & 109 & 122 & 35 & 42 & 117 & 1282 \\
\hline Tarkwa & 18 & 32 & 30 & 50 & 52 & 43 & 66 & 17 & 31 & 17 & 30 & 14 & 400 \\
\hline
\end{tabular}

TABLE XI: SUMMARY OF MONTHLY OUTAGES FOR THE LV GRID FOR THE YEAR 2016

\begin{tabular}{ccccccccccccccc}
\hline Operational Districts & Jan & Feb & March & April & May & June & July & Aug & Sept & Oct & Nov & Dec & Total \\
\hline Asankragwa & 12 & 13 & 22 & 19 & 10 & 24 & 15 & 17 & 14 & 26 & 23 & 18 & 213 \\
Axim & 63 & 59 & 70 & 68 & 70 & 64 & 58 & 69 & 59 & 52 & 69 & 61 & 762 \\
Bogoso & 23 & 17 & 20 & 15 & 22 & 31 & 12 & 19 & 14 & 26 & 65 & 36 & 300 \\
Enchi & 26 & 29 & 32 & 27 & 32 & 39 & 31 & 26 & 21 & 25 & 30 & 29 & 347 \\
Half Assini & 33 & 38 & 52 & 34 & 48 & 55 & 28 & 33 & 36 & 29 & 37 & 33 & 456 \\
Sefwi Wiawso & 52 & 47 & 29 & 41 & 33 & 54 & 47 & 45 & 52 & 39 & 55 & 51 & 545 \\
Sekondi & 200 & 217 & 186 & 198 & 234 & 269 & 241 & 222 & 206 & 234 & 229 & 217 & 2653 \\
Takoradi & 302 & 347 & 283 & 267 & 311 & 246 & 235 & 280 & 274 & 238 & 249 & 241 & 3273 \\
Tarkwa & 135 & 91 & 119 & 120 & 110 & 96 & 100 & 121 & 110 & 105 & 122 & 116 & 1345 \\
\hline
\end{tabular}

TABLE XII: SUMMARY OF FAULTS IN THE 33 KV DISTRIBUTION GRID FOR THE YEAR 2016

\begin{tabular}{|c|c|c|c|c|c|c|c|c|c|c|c|c|c|}
\hline \multirow[b]{2}{*}{$\begin{array}{l}\text { Operational } \\
\text { Districts }\end{array}$} & \multirow[b]{2}{*}{$\begin{array}{c}\text { Total Outage } \\
\text { Frequency/Year }\end{array}$} & \multirow[b]{2}{*}{$\begin{array}{c}\text { Total Outage } \\
\text { Duration } \\
\text { (Hours)/year }\end{array}$} & \multirow[b]{2}{*}{$\begin{array}{l}\text { Planned } \\
\text { Outages }\end{array}$} & \multicolumn{9}{|c|}{ Unplanned Outages } & \multirow[b]{2}{*}{$\begin{array}{c}\text { Outage Due } \\
\text { to Load } \\
\text { Shedding }\end{array}$} \\
\hline & & & & $\begin{array}{l}\text { Phase } \\
\text { Fault }\end{array}$ & $\begin{array}{l}\text { Earth } \\
\text { Fault }\end{array}$ & $\begin{array}{c}\text { Falling } \\
\text { Tree } \\
\text { Fault } \\
\end{array}$ & $\begin{array}{c}\text { Blown } \\
\text { Fuse } \\
\text { Fault } \\
\end{array}$ & $\begin{array}{c}\text { Conductor } \\
\text { Related } \\
\text { Fault } \\
\end{array}$ & $\begin{array}{c}\text { Loose } \\
\text { Contact } \\
\text { Fault } \\
\end{array}$ & $\begin{array}{c}\text { Surge } \\
\text { Arrester } \\
\text { Failure } \\
\end{array}$ & $\begin{array}{c}\text { Outage Due } \\
\text { to Faulty } \\
\text { Equipment }\end{array}$ & $\begin{array}{c}\text { Outage } \\
\text { Due to Bad } \\
\text { Weather }\end{array}$ & \\
\hline Asankragwa & 657 & 447.62 & 71 & 45 & 74 & 14 & & 15 & $\mathrm{x}$ & 2 & 5 & 147 & 284 \\
\hline Axim & 581 & 381.31 & 115 & 66 & 12 & 37 & 23 & 32 & $\mathrm{x}$ & $\mathrm{x}$ & $\mathrm{x}$ & 145 & 151 \\
\hline Bogoso & 975 & 797.8 & 147 & 38 & 52 & 14 & 45 & 26 & $\mathrm{x}$ & $\mathrm{x}$ & 8 & 277 & 368 \\
\hline Enchi & 298 & 1839.43 & 47 & 9 & 5 & $\mathrm{x}$ & 8 & $\mathrm{x}$ & $\mathrm{x}$ & $\mathrm{x}$ & 62 & 75 & 92 \\
\hline Half Assini & 230 & 2921.24 & 55 & 21 & 32 & $\mathrm{x}$ & $\mathrm{x}$ & $\mathrm{x}$ & $\mathrm{x}$ & $\mathrm{x}$ & 35 & 35 & 52 \\
\hline Sefwi Wiawso & 1425 & 1149.23 & 187 & 102 & 86 & $\mathrm{x}$ & 4 & 8 & $\mathrm{x}$ & $\mathrm{x}$ & 23 & 447 & 568 \\
\hline Sekondi & 699 & 901.5 & 84 & 23 & 45 & $\mathrm{x}$ & 6 & 8 & $\mathrm{x}$ & $\mathrm{x}$ & $\mathrm{x}$ & 274 & 259 \\
\hline Takoradi & 668 & 1334.62 & 74 & 56 & 120 & 60 & 23 & 74 & $\mathrm{x}$ & 2 & $\mathrm{x}$ & 103 & 156 \\
\hline Tarkwa & 360 & 656.1 & $\mathrm{x}$ & $\mathrm{x}$ & $\mathrm{x}$ & 32 & $\mathrm{x}$ & 25 & $\mathrm{x}$ & $\mathrm{x}$ & 23 & 93 & 187 \\
\hline
\end{tabular}


TABLE XIII: SUMMARY OF FAULTS IN THE 11 KV DISTRIBUTION GRID FOR THE YEAR 2016

\begin{tabular}{|c|c|c|c|c|c|c|c|c|c|c|c|c|c|}
\hline \multirow[b]{2}{*}{$\begin{array}{c}\text { Operational } \\
\text { Districts }\end{array}$} & \multirow[b]{2}{*}{$\begin{array}{l}\text { Total Outage } \\
\text { Frequency/Year }\end{array}$} & \multirow[b]{2}{*}{$\begin{array}{c}\text { Total Outage } \\
\text { Duration } \\
\text { (Hours)/year }\end{array}$} & \multirow[b]{2}{*}{$\begin{array}{l}\text { Planned } \\
\text { Outages }\end{array}$} & \multicolumn{10}{|c|}{ Unplanned Outages } \\
\hline & & & & $\begin{array}{l}\text { Phase } \\
\text { Fault }\end{array}$ & $\begin{array}{l}\text { Earth } \\
\text { Fault }\end{array}$ & $\begin{array}{c}\text { Falling } \\
\text { Tree } \\
\text { Fault }\end{array}$ & $\begin{array}{l}\text { Blown } \\
\text { Fuse } \\
\text { Fault }\end{array}$ & $\begin{array}{c}\text { Conductor } \\
\text { Related } \\
\text { Fault }\end{array}$ & $\begin{array}{c}\text { Loose } \\
\text { Contact } \\
\text { Fault }\end{array}$ & $\begin{array}{c}\text { Surge } \\
\text { Arrester } \\
\text { Failure }\end{array}$ & $\begin{array}{c}\text { Outage Due } \\
\text { to Faulty } \\
\text { Equipment }\end{array}$ & $\begin{array}{l}\text { Outage } \\
\text { Due to } \\
\text { Bad } \\
\text { Weather }\end{array}$ & $\begin{array}{l}\text { Outage } \\
\text { Due to } \\
\text { Load } \\
\text { Shedding }\end{array}$ \\
\hline Axim & 77 & 175.24 & 22 & $\mathrm{x}$ & $\mathrm{x}$ & & 15 & 7 & $\mathrm{x}$ & $\mathrm{x}$ & 6 & 14 & 13 \\
\hline $\begin{array}{c}\text { Sefwi } \\
\text { Wiawso }\end{array}$ & 474 & 530.1 & 55 & 32 & 52 & $\mathrm{x}$ & $\mathrm{x}$ & 8 & $\mathrm{x}$ & $\mathrm{x}$ & 21 & 144 & 162 \\
\hline Sekondi & 978 & 1977.4 & 22 & $\mathrm{x}$ & $\mathrm{x}$ & 25 & & 8 & $\mathrm{x}$ & $\mathrm{x}$ & $\mathrm{x}$ & 587 & 336 \\
\hline Takoradi & 1282 & 4973.44 & 147 & $\mathrm{x}$ & 47 & & 54 & 25 & $\mathrm{x}$ & 2 & 42 & 470 & 495 \\
\hline Tarkwa & 400 & 825.53 & 22 & $\mathrm{x}$ & 21 & 15 & 28 & 14 & $\mathrm{x}$ & & & 147 & 153 \\
\hline
\end{tabular}

TABLE XIV: SUMMARY OF FAULTS IN THE LV DISTRIBUTION NETWORK FOR THE YEAR 2016

\begin{tabular}{|c|c|c|c|c|c|c|c|c|c|c|c|c|c|}
\hline \multirow[b]{2}{*}{$\begin{array}{c}\text { Operational } \\
\text { Districts }\end{array}$} & \multirow[b]{2}{*}{$\begin{array}{c}\text { Total } \\
\text { Outage } \\
\text { Frequency } \\
\text { /Year }\end{array}$} & \multirow[b]{2}{*}{$\begin{array}{l}\text { Total Outage } \\
\text { Duration } \\
\text { (Hours)/year }\end{array}$} & \multicolumn{11}{|c|}{ Unplanned Outages } \\
\hline & & & $\begin{array}{l}\text { Planned } \\
\text { Outages }\end{array}$ & $\begin{array}{l}\text { Phase } \\
\text { Fault }\end{array}$ & $\begin{array}{l}\text { Earth } \\
\text { Fault }\end{array}$ & $\begin{array}{c}\text { Falling } \\
\text { Tree } \\
\text { Fault }\end{array}$ & $\begin{array}{l}\text { Blown } \\
\text { Fuse } \\
\text { Fault }\end{array}$ & $\begin{array}{c}\text { Conductor } \\
\text { Related } \\
\text { Fault }\end{array}$ & $\begin{array}{c}\text { Loose } \\
\text { Contact } \\
\text { Fault }\end{array}$ & $\begin{array}{l}\text { Surge } \\
\text { Arrester } \\
\text { Failure }\end{array}$ & $\begin{array}{c}\text { Outage } \\
\text { Due to } \\
\text { Faulty } \\
\text { Equipment }\end{array}$ & $\begin{array}{c}\text { Outage } \\
\text { Due to } \\
\text { Bad } \\
\text { Weather }\end{array}$ & $\begin{array}{c}\text { Outage } \\
\text { Due to } \\
\text { Load } \\
\text { Shedding }\end{array}$ \\
\hline Asankragwa & 213 & 228.5 & 28 & $\mathrm{x}$ & $\mathrm{x}$ & 23 & 42 & $\mathrm{x}$ & 45 & $\mathrm{x}$ & $\mathrm{x}$ & 75 & $\mathrm{x}$ \\
\hline Axim & 762 & 164.1 & 48 & $\mathrm{x}$ & $\mathrm{x}$ & 25 & 154 & 45 & 187 & $\mathrm{x}$ & 5 & 298 & $\mathrm{x}$ \\
\hline Bogoso & 300 & 888.2 & 52 & $\mathrm{x}$ & $\mathrm{x}$ & 23 & 54 & 42 & 56 & $\mathrm{x}$ & 31 & 42 & $\mathrm{x}$ \\
\hline Enchi & 347 & 450.8 & 45 & 7 & $\mathrm{x}$ & $\mathrm{x}$ & 154 & 38 & 45 & $\mathrm{x}$ & 12 & 46 & $\mathrm{x}$ \\
\hline Half Assini & 456 & 916.63 & 52 & 78 & $\mathrm{x}$ & 7 & 62 & 87 & 78 & $\mathrm{x}$ & 9 & 83 & $\mathrm{x}$ \\
\hline $\begin{array}{c}\text { Sefwi } \\
\text { Wiawso }\end{array}$ & 545 & 524.2 & 142 & 56 & $\mathrm{x}$ & 23 & 45 & 13 & 78 & $\mathrm{x}$ & 14 & 174 & $\mathrm{x}$ \\
\hline Sekondi & 2653 & 3857.6 & 203 & 47 & $\mathrm{x}$ & 21 & 805 & 104 & 774 & $\mathrm{x}$ & 41 & 658 & $\mathrm{x}$ \\
\hline Takoradi & 3273 & 2060.6 & 257 & $\mathrm{x}$ & $\mathrm{x}$ & 12 & 741 & 174 & 785 & $\mathrm{x}$ & 25 & 1279 & $\mathrm{x}$ \\
\hline Tarkwa & 1345 & 1965.6 & 154 & $\mathrm{x}$ & $\mathrm{x}$ & 42 & 391 & 45 & 324 & $\mathrm{x}$ & 15 & 374 & $\mathrm{x}$ \\
\hline
\end{tabular}

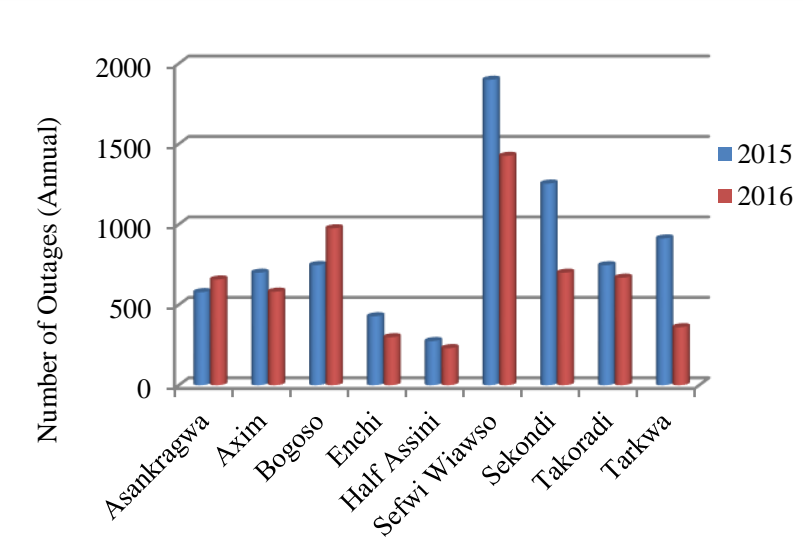

Operational Districts

Fig. 8. Graph of Total Outages for the $33 \mathrm{kV}$ Grid for the Years 2015 and 2016

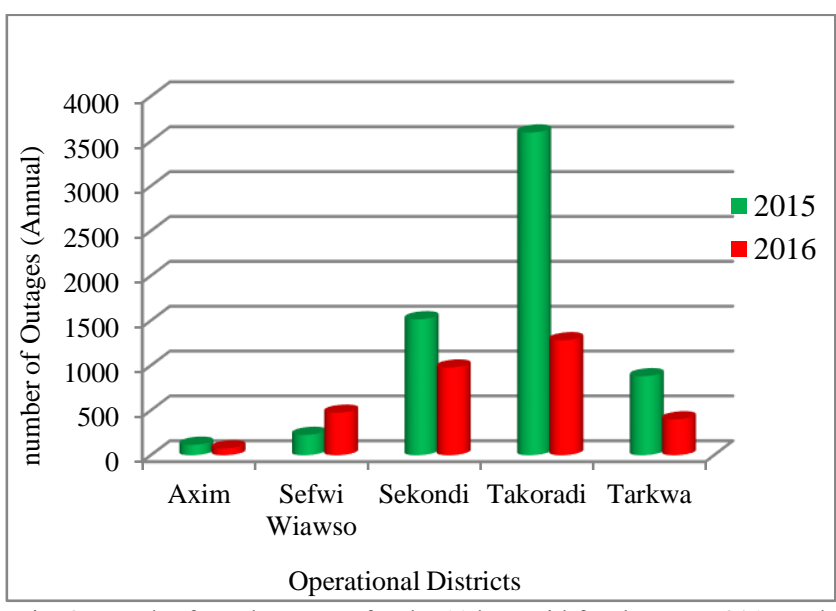

Fig. 9. Graph of Total Outages for the $11 \mathrm{kV}$ Grid for the Years 2015 and 2016

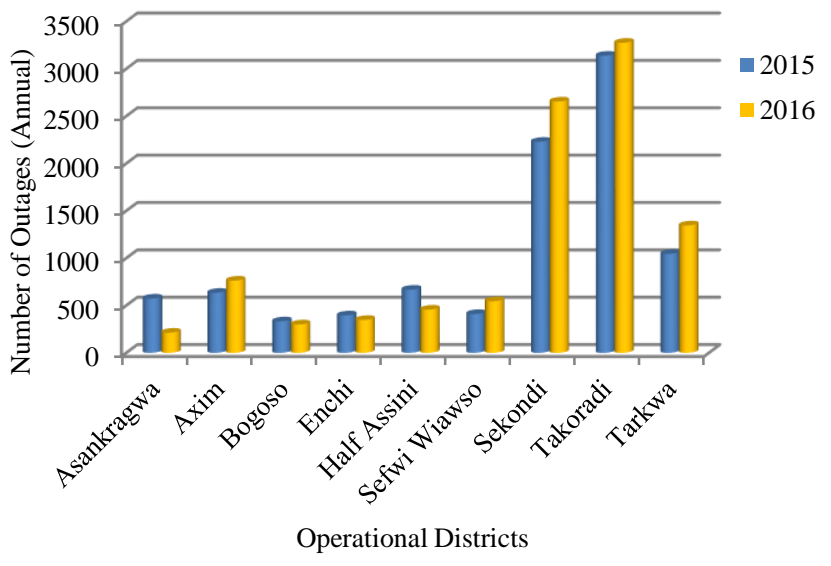

Fig. 10. Graph of Total Outages for the LV Grid for the Years 2015 and 2016.

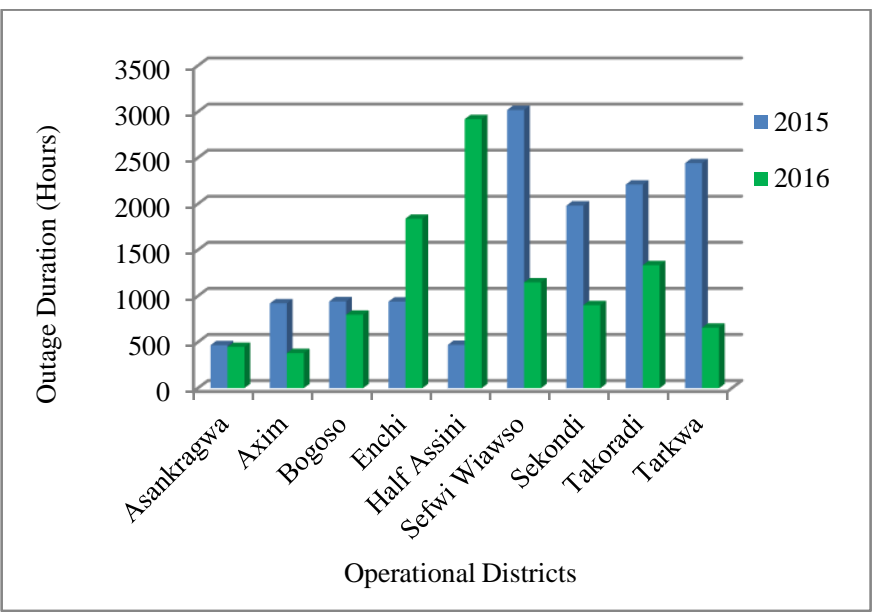

Fig. 11. Graph of Annual Outage Durations for the $33 \mathrm{kV}$ Grid for the Years 2015 and 2016 


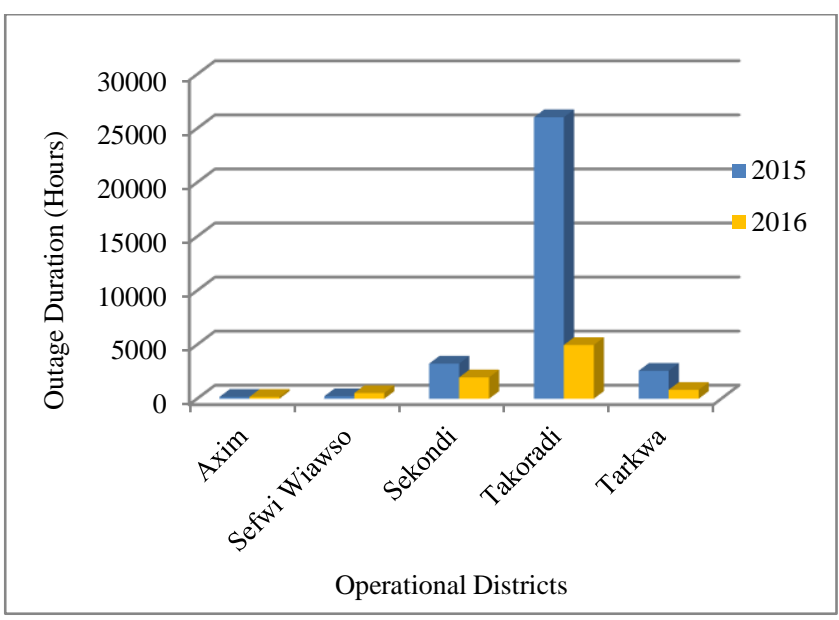

Fig.12. Graph of Annual Outage Durations for the $11 \mathrm{kV}$ Grid for the Years 2015 and 2016 .

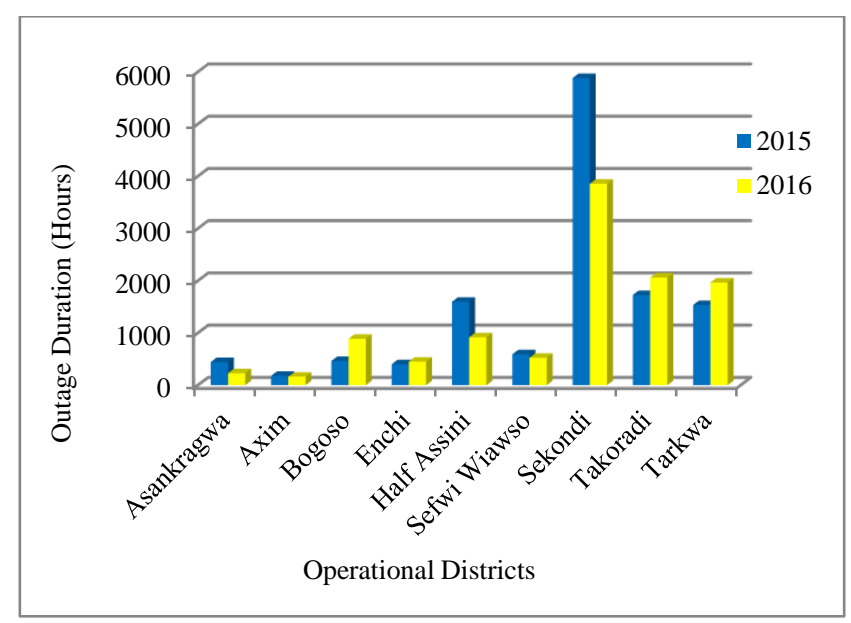

Fig. 13. Graph of Annual Outage Durations for the LV Grid for the Years 2015 and 2016.

\section{DISCUSSION OF RESULTS}

In the year 2015, the operational district with the highest number of outages (planned and unplanned) occurring in the $33 \mathrm{kV}$ electric power distribution grid is Sefwi Wiawso ECG operational district. The total number of outages (planned and unplanned) stood at 1898 lasting for 3019.4 hours. Followed closely was Sekondi ECG operational district with a total number of outages (planned and unplanned) at 1253 lasting for 1982.2 hours as given in Table VI as well as Fig. 8 and Fig. 11, respectively. Takoradi operational district experienced the highest number of outages (planned and unplanned) in the 11 $\mathrm{kV}$ electric power distribution grid which stood at 3597 lasting for 26039.9 hours. Sekondi ECG operational district followed closely with 1515 number of outages (planned and unplanned) lasting for 3253.3 hours as respectively given in Table VII as well as Fig. 9 and Fig. 12. Takoradi ECG operational district had 3136 planned and unplanned outages lasting for 1727.54 hours, followed by Sekondi operational district of a total number of planned and unplanned outages of 2228 lasting for 5881.9 hours in the LV electric power distribution grid as given in Table VIII as well as Fig. 10 and Fig. 13, respectively.

For the year 2016, Sefwi Wiawso ECG operational district again experienced a total number of planned and unplanned outages of 1425 lasting for 1149.23 hours. Bogoso operational district followed closely with 975 planned and unplanned outages lasting for 797.8 hours in the $33 \mathrm{kV}$ electric power distribution grid as shown in Table XII as well as Fig. 8 and Fig. 11, respectively. This contrast sharply with that of Half Assini operational district with only 230 planned and unplanned outages lasting for 2921.24 hours. Takoradi ECG operational district had 1282 planned and unplanned outages lasting for 4973.44 hours, followed by Sekondi operational district with 978 planned and unplanned outages lasting for 1977.4 hours in the $11 \mathrm{kV}$ electric power distribution grid as indicated in Table XIII as well as Fig. 9 and Fig. 12, respectively. Takoradi operational district experienced a total of 3273 planned and unplanned outages lasting for 2060.6 hours, followed by Sekondi operational district with 2653 planned and unplanned outages lasting for 3857.6 hours in the LV electric power distribution grid as shown in Table XIV as well as Fig. 10 and Fig. 13, respectively. Comparing Table 3 and Table 9 for the year 2015 and 2016 respectively, the total number of outages experienced on the Sefwi Wiawso ECG operational district $33 \mathrm{kV}$ feeder reduced marginally from 1898 to 1425 . The same thing can be said of the $11 \mathrm{kV}$ feeder for Takoradi and Sekondi ECG operational districts. Whilst the outage declined from 3597 in the year 2015 to 1282 in the year 2016 as indicated respectively by Table IV and Table X. That of Sekondi ECG operational district declined marginally from 1515 in the year 2015 to 978 in the year 2016 on the $11 \mathrm{kV}$ feeder. The tally for the LV distribution network showed that the total faults for Takoradi ECG operational district increased marginal from 3136 in the year 2015 to 3273 in the year 2016 as illustrated respectively by Table V and Table XI1. The same thing can be said of Sekondi ECG operational district. The total number of faults that occurred in the LV distribution network increased from 2228 in the year 2015 to 2653 in the year 2016 as indicated by Table V and Table XI respectively.

\section{CONCLUSION}

Outages due to bad weather and load shedding contributed significantly to the unplanned outages that occurred in the MV electric power distribution grid. Falling tree and instantaneous earth faults also played a major role. Blown fuse faults and loose contact faults were the major contributors to unplanned outages in the LV electric power grid. For both MV and LV electric power distribution grids, planned outages were minor as compared to unplanned outages that occurred.

\section{ACKNOWLEDGMENT}

The author would like to acknowledge the management and the entire staff of Western regional office of the Electricity Company of Ghana for their support.

\section{REFERENCES}

[1] Chowdhury, A. A., and Koval, D. O., Power Distribution System Reliability, Practical Methods and Applications; A John Wiley \& Sons, Inc., Publication, Hoboken, New Jersey, USA, 2009, pp. 1-10.

[2] Cepin, M., Assessment of Power System Reliability, Methods and Applications; Springer, London, UK, 2011, pp. 1-294.

[3] Brown, R. E., Electric Power Distribution Reliability, $2^{\text {nd }}$ edition, CRC Press, Taylor \& Francis Group, NW, USA, 2009, pp. 1-453.

[4] Gonen, T., Electric Power Distribution System Reliability Engineering, 
$2^{\text {nd }}$ edition, CRC Press, Taylor \& Francis Group, NW, USA, 2008, pp. $1-45$.

[5] Pabla, A. S., Electric Power Distribution, $6^{\text {th }}$ edition, McGraw-Hill Education, New Delhi, India, 2012, pp. 2-12.

[6] Elhaffar, A. M., "Power Transmission Line Fault Location Based on Current Traveling Waves", PhD Thesis, Helsinki University of Technology, Espoo, Finland, 2008, pp. 1-5.

[7] Iżykowski, J., "Power System Faults", Wrocław University of Technology, Wrocław, 2011, pp. 1-10.

[8] Musa, B. U., Ngajia, T. B., Kalli. B. M. and Tijjani, B. U., "Outage Analysis on Distribution Feeder in North East Nigeria", Journal of Multidisciplinary Engineering Science and Technology, Vol. 2, Issue 1, 2015, pp. 1-4.

[9] . Osabohien, R. W. and Uhunmwangho, R., "Assessing The Impacts of Distributed Generation on the Protection Scheme of a Distribution Network: Trans Amadi 33 kV Distribution Network as a Case Study", Nigerian Journal of Technology. Vol. 37, No. 1, 2018, pp. 209-215.

[10] Thakre, M., Gawre, S. K. and Mishra, M. K., "Distribution System Faults Classification And Location Based On Wavelet Transform", International Journal on Advanced Computer Theory and Engineering, Vol. 2, Issue 4, 2013, pp. 2319-2526.

[11] Shalangwa, D. A., Shinggu, D. Y., and T. Jonathan, T., “An Analysis of Electric Power Faults in Mubi Undertaking Station, Adamawa State, Nigeria", The Pacific Journal of Science and Technology, Vol. 10, No. 2, 2009, pp. 508-513.

[12] Musa, B. U., Ngajia, T. B., Kalli, B. M and Tijjani, B. U., "Outage Analysis on Distribution Feeder in North East Nigeria", Journal of Multidisciplinary Engineering Science and Technology, Vol. 2, Issue 1, 2015, pp. 149-152.

[13] Gonen, T., Electrical Power Transmission System Engineering Analysis and Design, ${ }^{\text {rd }}$ Edition, CRC Press, Sacramento, USA, 2014 pp. 575-600.

[14] Davis, W. P., "Analysis of Faults in Overhead Transmission Lines", M.Sc. Thesis, California State University, Sacramento, U.S.A. 2012, pp. $1-15$.

[15] Roy, P., and Gupta, S. K., "Digital Technique of fault study of power system", International Research Journal of Engineering and Technology, Vol. 3, Issue 7, 2016, pp. 162-169.

[16] Wang, L., "The Fault Causes of Overhead Lines in Distribution Network", the International Seminar on Applied Physics, Optoelectronics and Photonics, Shanghai, China, May 28-29, 2016 pp. 1-5.

[17] Panth, D., "Reasons for Failure of Transmission Lines and their Prevention Strategies", International Journal of Electrical, Electronics and Data Communication, Vol. 2, Issue 1, 2014, pp. 1-4. 